\title{
SOLITARNI FIBROZNI TUMOR PLEURE - PRIKAZ SERIJE SLUČAJEVA I PREGLED LITERATURE
}

\author{
SOLITARY FIBROUS TUMOR OF THE PLEURA -SERIES OF CASES AND REVIEW OF THE \\ LITERATURE
}

\begin{abstract}
Aleksandra Lovrenski, Ivana Jeličić, Dragana Tegeltija, Miloš Koledin, Milorad Bijelović, Milana Panjković
\end{abstract}

\begin{abstract}
SAŽETAK: Uvod: Solitarni fibrozni tumor pleure (SFTP) je redak, spororastući primarni tumor pleure koji vodi poreklo od mezenhimalnih ćelija u submezotelnom sloju pleure. Cilj: Analiza 18 pacijenata sa SFTP sa akcentom na demografske, kliničko-morfološke, histološke i imunohistohemijske karakteristike ove neoplazme, naročito u diferencijaciji benignih od malignih formi. Metode: Sprovedena je retrospektivna analiza kliničkih podataka 18 pacijenata sa patohistološki dijagnostikovanim SFTP u desetogodišnjem periodu na Institutu za plućne bolesti Vojvodine. Rezultati: Prosečna starost pacijenata bila je 54 godine. 61.1\% pacijenata bilo je ženskog, a 38.9\% muškog pola. 44,4\% pacijenata bili su pušači. Najčešće kliničke manifestacije bile su bol u hemitoraksu (44,4\%), kašalj (38.8\%) $i$ opšti infektivni sindrom (22,2\%). Tumor je bio lokalizovan u desnom hemitoraksu u $61.2 \%$ pacijenata, a kod $38.8 \%$ u levom. Najmanji dijametar tumora bio je $2 \mathrm{~cm}$, a najveći $15 \mathrm{~cm}$. U jednom slučaju SFTP se prezentovao kao maligni tumor, a u jednom slučaju kao „,borderline“ tumor nepredvidivog biološkog ponašanja usled prisustva nekroze, povećane celularnosti i veličine od $13 \mathrm{~cm}$. Vimentin, CD34 i bcl-2 su se pokazali kao pouzdana pozitivna, a CD31, EMA, dezmin and panCK kao pouzdana negativna antitela u dijagnozi ovog tumora. Zaključak: Granica između benignih i malignih SFTP nije jasno definisana, te se u postavljanju konačne dijagnoze $i$ terapijskog postupka, kao i predviđanju toka bolesti moraju uključiti svi dostupni demografski, klinički, morfološki i imunohistohemijski podaci.
\end{abstract}

Ključne reči: solitarni fibrozni tumor, pleura, dijagnoza.

\section{UVOD}

Solitarni fibrozni tumor pleure (SFTP) je redak sporo-rastući primarni tumor pleure koji vodi poreklo od ćelija mezenhimnog tkiva koje se nalaze u submezotelnom sloju pleure. Njegova učestalost među primarnim tumorima pleure kreće se $4-5 \%$. Najčešće nastaje od visceralnog lista pleure. ${ }^{1}$ To je podmukla neoplazma koja se u preko $50 \%$ slučajeva prezentuje asimptomatski i najčešće se otkriva slučajnim rendgenogramom pluća. Simptomi nastaju kada tumor dosegne velike dimenzije $i$ to su najčešće: kašalj, bol u grudima i dispnea, a ređe hematemeza, gripozni sindrom, gubitak na telesnoj težini i sinkopa. ${ }^{1,2}, 3$ Radiološki, najčešće se prezentuju u vidu dobro ograničenih, homogenih, okruglih masa čija veličina varira od malih $(1 \mathrm{~cm})$ pa sve do veoma velikih $(36 \mathrm{~cm})$ koje okupiraju ceo hemitoraks. ${ }^{3}$
Makroskopski, SFTP se uočava kao okruglasta, lobulirana masa glatke površine. Najveći broj tumora inkapsulisan je tankom, translucidnom kapsulom koja je prožeta bogatom vaskularnom mrežom, dok manji broj tumora pokazuje prisustvo sekundarnih promena u vidu cističnih formacija, hemoragije, kalcifikacije i nekroze (Slika 1.). ${ }^{3}$

Mikroskopski, SFTP čine dva osnovna elementa koja su prisutna u različitom odnosu. Jednu komponentu čine solidne nakupine vretenastih ćelija, dok je druga komponenta izgrađena od snopova sklerozirajućeg vezivnog tkiva (Slika 2.).

Vretenaste ćelije pokazuju brojne varijacije u svom izgledu i formacijama koje grade što može predstavljati problem prilikom diferencijalne dijagnoze. Ove ćelije mogu formirati vrtložaste strukture koje podsećaju na fibrohistocitne tumore ili mogu podsećati na epiteloidne ćelije koje, udružene sa brojnim razgranatim vaskularnim strukturama, mogu dati sliku hemangiopericitoma 
(Slika 3.). Jedra su često palisadno raspoređena i podsećaju na riblju kost. Difuzna sklerozirajuća komponenta tumora pokazuje često degenerativne promene $\mathrm{u}$ vidu miksoidnih matriksnih depozita, degeneracije kolagena i metaplastičnih koštanih formacija. ${ }^{4}$

SFTP su najčešće benigne neoplazme koje se mogu $\mathrm{u}$ potpunosti otkloniti lokalnom ekscizijom tumora, pri čemu se mora obratiti pažnja na to da $\mathrm{i}$ peteljka tumora bude odstranjena. Međutim, 5-10\% tumora pokazuje lošu ograničenost i infiltraciju okolnog tkiva, kao i visoku mitotsku aktivnost udruženu sa pleomorfizmom jedara i povećanim nukleo-citoplazmatskim odnosom, pa se zbog toga svrstavaju u maligne neoplazme. ${ }^{3}$

Imunohistohemija omogućava prevazilaženje diferencijalno dijagnostičkih dilema i ima veoma važnu ulogu u postavljanju dijagnoze SFTP. Međutim, kako nijedno antitelo ne poseduje 100\% specifičnost i visoku senzitivnost dajući tako $100 \%$ potvrdu ili isključenje dijagnoze SFTP, danas je visoko preporučljiva upotreba palete antitela koja predstavlja kombinaciju dva ili više antitela. ${ }^{5}$

U našem radu analizirali smo 18 slučajeva SFTP sa akcentom na demografske, kliničke, morfološke, histološke i imunohistohemijske odlike ove neoplazme, posebno u diferenciranju benignih $\mathrm{i}$ malignih SFTP.

\section{METODE}

Ispitivanje je obuhvatilo 18 pacijenata kod kojih je, na Institutu za plućne bolesti Vojvodine u Sremskoj Kamenici, dijagnostikovan solitarni fibrozni tumor pleure (SFTP) u desetogodišnjem periodu. Materijal za patohistološku i imunohistohemijsku analizu obrađen je i analiziran u Centru za patologiju. Analizirani su: starosna dob pacijenata, pol, pušenje, simptomi bolesti, lokalizacija i veličina tumora, kao i makroskopske (prisustvo peteljke, inkapsulisanost, vezanost za visceralnu ili parijetalnu pleuru, krvarenje) i histološke karakteristike tumora (nekroza, celularnost, mitotska aktivnost tumorskih ćelija i imunofenotip tumorskih ćelija).

Bioptički materijali dobijeni su bronhoskopijom, transtorakalnom punkcijom (TTP) ili biopsijom pleure putem videoasistirane torakoskopije (engl. video-assisted thoracoscopic surgery - VATS), a nakon postavljanja dijagnoze promene su $\mathrm{u}$ potpunosti, zajedno sa svojom peteljkom, odstranjene i to putem VATS ili anterolateralne ili posterolateralne torakotomije.

Svi dobijeni uzorci fiksirani su u celini u $10 \%$ neutralnom formalinu i nakon kalupljenja u parafinu sečeni mikrotomom na tkivne isečke debljine 4 mikrona, a potom bojeni hematoksilin-eozin (HE) metodom. Uzorci za citološku analizu bojeni su metodom po May-Grünwald-Giemsa (MGG). Za IHH analize uzorci su lepljeni na „Superfrost“ (Men Glaser) pozitivno naelektrisane staklene pločice unapred pripremljene za IHH reakcije. Nakon deparafinisanja isečaka izvršeno je demaskiranje antigenih determinanti kuvanjem preparata $\mathrm{u}$ citratnom puferu $(\mathrm{pH}=6)$ dva puta po 10 minuta $\mathrm{i}$ hlađenjem u destilovanoj vodi 20 minuta. Zatim se pristupilo blokiranju endogene peroksidaze sa 3\% hidrogenom u trajanju od 5 minuta. Tako obrađeni preparati tretirani su primarnim antitelima i inkubirani 30 minuta sa biotiniliziranim mišijim antitelom, a zatim inkubirani još 30 minuta sa streptavidin-peroksidaza kompleks sistemom. Kao hromogeni supstrat upotrebljen je DAB (diaminobenzidin-tetrahidrohlorid) i izvršeno je kontrastiranje hematoksilinom. $\mathrm{Na}$ ovaj način imunohistohemijski obrađeni uzorci su zatim analizirani pod svetlosnim mikroskopom i na osnovu njihove pozitivnosti ili negativnosti na određeno antitelo postavljena je konačna dijagnoza solitarnog fibroznog tumora pleure.

\section{REZULTATI}

Ispitivanje je obuhvatilo 18 pacijenata sa dijagnostikovanim solitarnim fibroznim tumorom pleure. VATS je rađena kod svih 18 pacijenata $(100 \%)$, dok je bronhoskopija rađena kod 5 pacijenata $(27,7 \%)$ i kod svih je bronhoskopski nalaz bio uredan. TTP rađena je kod dva pacijenta, kod jednog nije razjasnila etiologiju bolesti dok je kod drugog pacijenta postavljena dijagnoza mezenhimalnog tumora.

Starosna dob pacijenata kretala se od 22 i 78 godina. Prosečna starost iznosila je 54 godine. Od 13 ispitivana pacijenata, njih $11(61,1 \%)$ je bilo ženskog pola, a preostalih $7(38,9 \%)$ muškog pola. 8 $(44,4 \%)$ pacijenata bili su pušači.

Bol u hemitoraksu, kašalj i opšti infektivni sindrom bile su najčešće kliničke manifestacije tumora pleure kod naših pacijenata. Kašalj je 
registrovan kod $7(38,8 \%)$ pacijenata, na bol u hemitoraksu žalilo se $8(44,4 \%)$ pacijenata, a opšti infektivni sindrom imala su $4(22,2 \%)$ pacijenta. Asimptomatska prezentacija SFTP bila je prisutna kod $8(44,4 \%)$ pacijenta.

SFTP lokalizovan u levom hemitoraksu imala su 7 pacijenta (38,8\%), dok je kod 11 pacijenata $(61,2 \%)$ SFTP nađen u desnom hemitoraksu.

Najmanji prečnik SFTP kod naših pacijenata iznosio je $2 \mathrm{~cm}$, a najveći $15 \mathrm{~cm}$. 7 pacijenata $(38,8 \%)$ imalo je prečnik tumora do $5 \mathrm{~cm}, 6$ pacijenta $(33,3 \%)$ prečnik između 6 i $10 \mathrm{~cm}$, a 5 pacijenta $(27,9 \%)$ tumor veći od $11 \mathrm{~cm}$.

Pet tumora imalo imalo je vidljivu peteljku kojom su bili vezani za pleuru, od čega je jedan tumor imao dve peteljke. Najmanja peteljka bila je dužine $0,3 \mathrm{~cm}$, dve peteljke bile su dužine po $1,5 \mathrm{~cm}$, dve dužine po $2 \mathrm{~cm}$, dok je najduža peteljka bila dužine $4 \mathrm{~cm}$.

Kod 17 pacijenata tumori su u potpunosti odstranjeni, od toga su kod dva pacijenta tumori odstranjeni zajedno sa režnjem pluća. Kod svih ovih 17 pacijenata, tumori su bili inkapsulisani, nisu pokazivali znake infiltracije pleure, a bili su ružičastobeličaste boje, lobulirani. U dva su bila prisutna manja žarišta svežeg krvarenja. Kod jedne pacijentkinje, tumor je bio infiltrativan i nakon sprovedene VATS i uzimanja bioptičkih uzoraka odustalo se od daljeg operativnog lečenja, tako da se makroskopske karakteristike tumora nisu mogle evaluirati.

17 tumora bilo je vezano za visceralnu, a 1 za parijetalnu pleuru.

Nekroza je bila prisutna samo u dva tumora. Jedan je bio maligan, infiltrativnih granica ka okolnom tkivu, sa prisutnim mitozama - 8/10 HPFhigh power field (8 mitoza na 10 vidnih polja velikog uveličanja/ $\mathrm{x} 40$ ). Drugi tumor je bio inkapsulisan, nije infiltrovao visceralnu pleuru, mitotski indeks bio je 4/10 HPF, ali je zbog prisutne nekroze, veličine i veće celularnosti označen kao tumor neodređenog malignog potencijala.

$\mathrm{U}$ preostalim tumorima nekroza nije bila prisutna, oni su bili umerene celularnosti i niskog mitotskog indeksa (ne više od 2/10 HPF).

Vimetin bio je pozitivan u $88,89 \%$ slučajeva, dok je S100 bio pozitivan u 50\% slučajeva. CD34 je rađen kod 15 pacijenata (Slika 4.), Bcl-2 kod 5 (Slika 5.), a CD99 kod 3 pacijenta i sva tri antitela su bila pozitivna u svim (100\%) tretiranim slučajevima. HBME-1, CD31 i EMA su bili negativni $u$ svim analiziranim slučajevima. Calretinin je rađen na 3, panCK i Desmin na po 6, a SMA na 10 slučajeva i u svim analiziranim uzorcima ova antitela su bila negativna.

\section{RASPRAVA}

Prvi zapis o ovom tumoru ostavio je Lientaud 1767. godine, dok je za njegovo svrstavanje $u$ primarne lokalizovane tumore pleure zaslužan Wagner. ${ }^{6}$ Klemper i Radin 1931. godine prvi daju patohistološki opis u kojem poreklo ovog tumora dovode u vezu sa ćelijama mezenhimalnog tkiva koje leži ispod mezotelnog sloja pleure. ${ }^{7}$

SFTP je, u literaturi, dijagnostikovan i opisan kod svih starosnih grupa. De Perrot i sar. u svojim radovima navode da je pik oboljevanja u šestoj $i$ sedmoj deceniji života, dok drugi autori navode podatak da se pik javljanja SFTP nalazi između pete i osme decenije ${ }^{8,9}$ Prosečna starost naših pacijenata iznosila je 54 godine, najmlađi pacijent uključen u naše istraživanje imao je 22 godine, a najstariji 78 godina. Našim istraživanjem potvrdili smo da ova neoplazma pogađa skoro sve starosne grupe, ali da se najčešće javlja posle 50 godine života.

U literaturi postoje istraživanja kod kojih se navodi predominacija SFTP kod ženskog pola, kao i istraživanja kod kojih je SFTP dominira kod muškog pola. Međutim, najveći broj literaturnih podataka na koje smo naišli složni su po pitanju distribucije SFTP kod muškaraca i žena. Ovi podaci navode da se neoplazma podjednako javlja kod oba pola $\mathrm{i}$ da ne postoji polna predispozicija za njeno razvijanje. ${ }^{10}$ Odnos pojave SFTP kod pacijenata obuhvaćenih našim istraživanjem iznosila je 1,6:1 na štetu ženskog pola.

Prethodna istraživanja rađena na velikom broju uzoraka, nisu naišla na vezu između nastanka SFTP i pušenja, ekspozicije azbestu i drugim agensima životne sredine. ${ }^{11,12} 46,1 \%$ pacijenata $u$ našem istraživanju su bili pušači.

SFTP se u preko $50 \%$ slučajeva prezentuje asimptomatski. Asimptomatska prezentacija SFTP među našim pacijentima iznosila je $44,4 \%$ potkrepljujuću njegov podmukao karakter. Simptomi nastaju kada tumor dosegne velike dimenzije i to su najčešće bol u grudima, kašalj i dispnea, a ređe hematemeza, gripozni sindrom, gubitak na telesnoj težini i sinkopa. Kao vodeći 
simptom kod naših pacijenata našao se bol $u$ hemitoraksu $(44,4 \%)$, a pratilo ga je prisustvo kašlja $(38,8 \%)$. Opšti infektivni sindrom, iako se navodi kao ređi simptom SFTP, javio kod 22,2\% pacijenata. Prethodna istraživanja ukazala su da je hipertrofična pulmonalna osteoartropatija najčešći paraneoplastični sindrom koji prati ovaj tumor $(22 \%){ }^{13}$ Zapažena je i pojava učestalih hipoglikemijskih sinkopa uzrokovanih insulin-like factor-II (IGF-II) koje luči 5\% tumora. ${ }^{13}$ Ovakvi simptomi i znaci nisu nađeni kod naših pacijenata. Od zanimljivijih i u literaturi jedinstvenih prezentacija SFTP navedene su epizode sinkope prilikom kašlja ${ }^{14}$, kao i štucanje refrakterno na medikamente i edem donjih ekstremiteta usled kompresije desnog atrijuma i donje šuplje vene. ${ }^{15,16}$

SFTP kod naših pacijenata bio je lokalizovan u desnom hemitoraksu kod 11 (61,2\%) pacijenata, a u levom kod 7 (38,8\%) pacijenata. Retrospektivnom analizom Guo i sar. koja je obuhvatila 39 pacijenata poređen je odnos pojave SFTP u levom i desnom hemitoraksu sa njegovim ponašanjem i prognozom gde nisu nađeni statistički značajne razlike. ${ }^{13}$

Proučavajući SFTP nađene su velike varijacije u njegovoj veličini. Veličina registrovanih tumora kreće se od 1,3 do $33 \mathrm{~cm}^{3}$ Cardillo $i$ sar. u svojoj analizi 110 pacijenata sa SFTP navode da ne postoji korelacija između veličine tumora $\mathrm{i}$ njegove prognoze. ${ }^{17}$ Postoje i istraživanja koja navode da su maligne varijante SFTP češće veličine preko $10 \mathrm{~cm} .^{3}$ Ovaj podatak treba uzeti kao pomoćni indikator u određivanju biološkog ponašanja tumora, ali nikako kao pouzdan. Najmanji prečnik SFTP kod naših pacijenata iznosio je $2 \mathrm{~cm}$, a najveći $15 \mathrm{~cm} .7$ pacijenata $(38,8 \%)$ imalo je prečnik tumora do $5 \mathrm{~cm}$, 6 pacijenta $(33,3 \%)$ prečnik između 6 i $10 \mathrm{~cm}$, a 5 pacijenta $(27,9 \%)$ tumor veći od $11 \mathrm{~cm}$. Maligna varijanta SFTP koja je nađena u našem istraživanju imala je prečnik $13 \mathrm{~cm}$ ukazujući tako na mogućnost korišćenja veličine kao putokaza ka lakšoj konačnoj diferencijaciji benignih od malignih SFTP.

Pet SFTP kod naših pacijenata imalo je vidljivu peteljku kojom su bili vezani za pleuru. Prethodna istraživanja takođe navode predominaciju sesilnih varijanti SFTP u odnosu na tumore sa peteljkom. ${ }^{13}$ Većina istraživanja navodi visceralnu pleuru kao vodeće mesto porekla kod SFTP. ${ }^{7,9,13}$ U našem istraživanju značajan broj SFTP, njih 17 , bio je porekla visceralne pleure.
Konačna dijagnoza SFTP postavlja se isključivo patohistološkim pregledom bioptiranog materijala uz pomoć imunohistohemije. Bioptički materijali dobijeni su bronhoskopijom, transtorakalnom punkcijom (TTP) i biopsijom pleure putem videoasistirane torakoskopije (VATS). Robinson u svom istraživanju navodi da bronhoskopski nalaz nije pouzdan u dijagnozi SFTP već da se koristi radi isključenja drugih neoplazmi. ${ }^{4}$ Bronhoskopija je rađena kod $5(27,7 \%)$ pacijenata $i$ kod svih je nalaz bio uredan ukazujući još jednom na validnost činjenice da bronhoskopija nije pouzdana $u$ postavljanju dijagnoze SFTP. Transtorakalna punkcija retko obezbeđuje dovoljno materijala za postavljanje definitivne dijagnoze i većina autora je ne preporučuje kao metodu prikupljanja bioptičkog materijala kod sumnje na ovu neoplazmu. ${ }^{3,4,17}$ Nasuprot njima Sung $i$ sar. u svom istraživanju navode uspešnost postavljanja definitivne dijagnoze transtorakalnom punkcijom od $43 \%{ }^{18} \mathrm{U}$ našem istraživanju TTP rađena je kod dva pacijenta, kod jednog nije razjasnila etiologiju bolesti dok je kod drugog pacijenta bila postavljena dijagnoza mezenhimalnog tumora. VATS se danas smatra prioritetnom i najefikasnijom metodom za uzimanje bioptičkog materijala za $\mathrm{PH}$ analizu. U odnosu na druge bioptičke metode daje bolju vizualizaciju uzorka sa izuzetno malim procentom komplikacija. VATS rađena je kod svih $18(100 \%)$ pacijenata uključenih $u$ naše istraživanje. Ovom metodom dobijeni su uzorci na kojima se PH pregledom uz upotrebu imunohistohemijske analize postavila konačna dijagnoza SFTP.

Granica između benignih i malignih SFTP nije u potpunosti jasna, niti definisana. Makroskopska prezentacija benignih $\mathrm{i}$ malignih tumora je $u$ najvećem broju slučajeva identična, u vidu okruglaste lobulirane mase glatke površine inkapsulisane translucidnom kapsulom. Sekundarne promene u vidu hemoragije, nekroze, kalcifikacije i cističnih formacija javljaju se i kod benignih i kod malignih formi. Manja predominacija sekundarnih promena koja se nalazi kod malignih formi vezuje se za postojanje većeg dijametra ovih formi. ${ }^{1,3}$ England i sar. su kao mikroskopske kriterijume za malignitet predložili hipercelularnost, pleomorfizam i preklapanje jedara, nekrozu, hemoragiju i više od 4 mitotske aktivnosti na 10 vidnih polja velikog uvećanja. ${ }^{12}$ Međutim samo $55 \%$ na ovaj način dijagnostikovanih malignih SFTP pokazalo je 
agresivnost $u$ vidu infiltracije, rekurencije $i$ metastaziranja. Carretta $i$ sar. su smatrali da tri od navedenih kriterijuma klasifikuju ove tumore $\mathrm{u}$ kategoriju malignih. ${ }^{19}$ Vallat-Decouvelaere $i$ sar. utvrdili su da histološke karakteristike SFTP nisu uvek u skladu sa njihovim ponašanjem, pokazavši da postoje i oni SFTP koji su pokazali invaziju koštanih i mekih struktura grudnog koša i rekurenciju, a da pri tome nisu zadovoljili neki od prethodno navedenih kriterijuma maligniteta. ${ }^{20} \mathrm{Sa}$ druge strane, Christopher Fletcher, jedno od najvećih imena u savremenoj patologiji, smatra da se samo prisustvo više od 4 mitoze na 10 HPF može smatrati validnim kriterijumom za malignitet. ${ }^{21} \mathrm{U}$ našem istraživanju nekroza je bila prisutna kod dva tumora od kojih je jedan klasifikovan kao maligni usled prisustva infiltracije i mitotskog indexa većeg od 8/10 HPF, dok je drugi klasifikovan kao tumor neodređenog malignog potencijala zbog veličine $(13 \mathrm{~cm})$, prisustva nekroze i povećane celularnosti uz odsustvo infiltracije. Preostali SFTP bili su inkapsulisani, bez nekroze, umerene celularnosti i mitotskog indexa do 2/10 HPF te su klasifikovani kao benigni. Međutim, kako histološke karakteristike ovog tumora nisu uvek u korelaciji sa njegovim biološkim ponašanjem, najveći broj autora smatra da SFTP treba tretirati kao granične tumore i da ih obavezno treba hirurški odstraniti.

Imunohistohemija omogućava prevazilaženje diferencijalno dijagnostičkih dilema i ima veoma važnu ulogu u postavljanju dijagnoze SFTP. Litreraturni podaci navode i preporučuju upotrebu velikog broja antitela i njihove različite kombinacije prilikom postavljanja dijagnoze SFTP. ${ }^{18}$

Antitela koja se najčešće koriste su: Vimentin, CD34, bcl-2, CD99, S100, CD31, CD117, dezmin i panCK. Prethodna istraživanja dokazala su da je SFTP generalno pozitivan na vimentin i negativan na panCK suprotno od malignog mezotelioma pleure koji često predstavlja najznačajniju problematiku prilikom diferencijalne dijagnoze i sa kojim se pre upotrebe imunohistohemije često izjednačavao. ${ }^{18}$ Međutim, nova istraživanja pokazala su da multifokalna pozitivnost na panCK ipak može biti prisutna u malignim formama ovog tumora što dodatno otežava dijagnozu. ${ }^{22}$ Našim istraživanjem dobili smo pozitivan nalaz kod sledećih antitela: vimentin (88,89\%), CD34 (100\%), bcl-2 (100\%), potvrđujući tako njihovu važnu ulogu kao očekivana pozitivna antitela prilikom potvrde dijagnoze SFTP.
Negativan nalaz u našem ispitivanju dala su sledeća antitela: CD31, EMA, CD117, Desmin i panCK. Kod svih ovih antitela negativan nalaz se našao kod $100 \%$ tretiranih uzoraka potvrđujući i ukazujući time na neophodnost njihove kombinacije sa očekivanim pozitivnim antitelima radi sigurnije konačne dijagnoze SFTP. Prilikom upotrebe S100 antitela dobijeni su različiti podaci. Mentzel $i$ sar. u svom istraživanju navode da je antitelo S100 pozitivno u $\mathrm{SFTP}^{23}$, dok su Demicco $i$ sar. na većoj seriji pacijena potvrdili da je S100 pouzdano negativno antitelo $\mathrm{u}$ dijagnozi SFTP. ${ }^{3}$ Ovim antitelom tretirano je 6 uzoraka u našem istraživanju, gde su $3(50 \%)$ dala pozitivan nalaz, a druga $3(50 \%)$ negativan potvrđujući tako mogućnost i pozitivnog i negativnog nalaza S100 kod SFTP. HBME-1 i Calretinin antitela su kod naših pacijenata bila negativna (100\%), slažući se tako sa rezultatima Mune $i$ sar. $^{24}$ Podaci o pozitivnom nalazu CD99 antitela kod SFTP govore $\mathrm{u}$ prilog njegovog učestalog pozitivnog nalaza, ali isto tako upozoravaju da se ovo antitelo javlja kao pozitivno i kod drugih neoplazmi kao što je sinovijalni sarkom. ${ }^{3}$ U našem istraživanju ovo antitelo rađeno je kod 3 pacijenta i u sva tri slučaja je bilo pozitivno.

Danas se STAT6 smatra najpouzdanijim antitelom za dijagnozu SFTP koje pokazuje specifičnost od skoro $100 \% .,{ }^{5,25,26}$ Nuklearna ekspresija STAT6 omogućava razlikovanje ovog tumora od drugih entiteta poput malignog mezotelioma, neuralnih tumora, monofaznog sinovijalnog sarkoma, fibrosarkoma i pleomorfnog sarkoma. ${ }^{27}$

Kako nijedno antitelo ne poseduje $100 \%$ specifičnost i visoku senzitivnost dajući tako $100 \%$ potvrdu ili isključenje dijagnoze SFTP, danas je visoko preporučljiva upotreba palete antitela koja predstavlja kombinaciju 2 ili više antitela. ${ }^{3,5,11}$

Što se terapijskog pristupa tiče, imperativ je kompletna hirurška resekcija sa obaveznim uklanjanjem i peteljke tumora ukoliko je prisutna kako bi se izbegli recidivi. Mali tumori mogu se zbrinuti VATS-om, dok veći zahtevaju torakotomiju. Seslini tumori vezani za visceralnu pleuru često moraju biti uklonjeni lobektomijom, a po potrebi i pneumonektomijom. Ukoliko je to neophodno, nakon operativnog lečenja može se aplikovati i neoadjuvantna terapija. ${ }^{17,18,19}$ 


\section{ZAKLJUČAK}

Granica između benignih i malignih SFTP nije u potpunosti jasna, niti definisana te se u postavljanju konačne dijagnoze i terapijskog postupka, kao i predviđanju toka bolesti moraju uključiti svi dostupni demografski, klinički, morfološki i imunohistohemijski podaci.

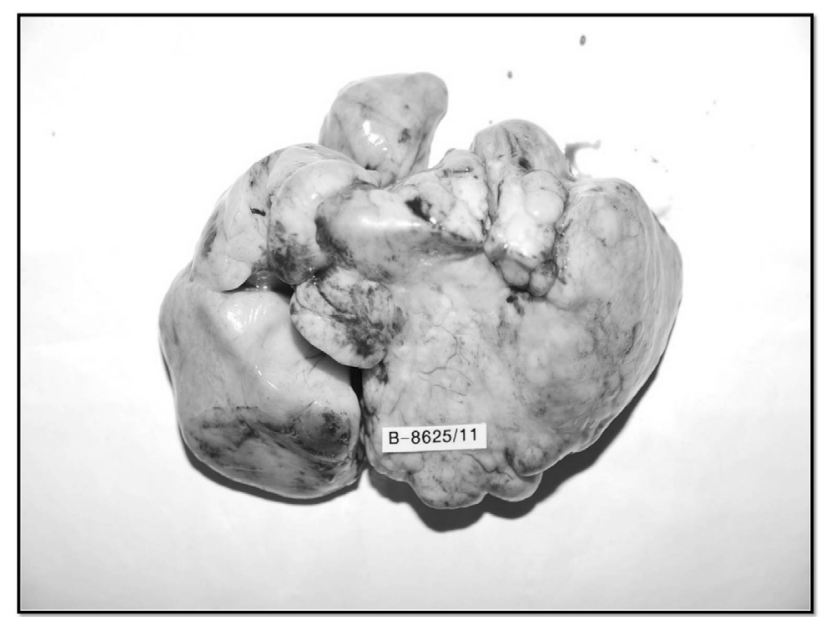

Slika 1. Solitarni fibrozni tumor pleure: makroskopski izgled.

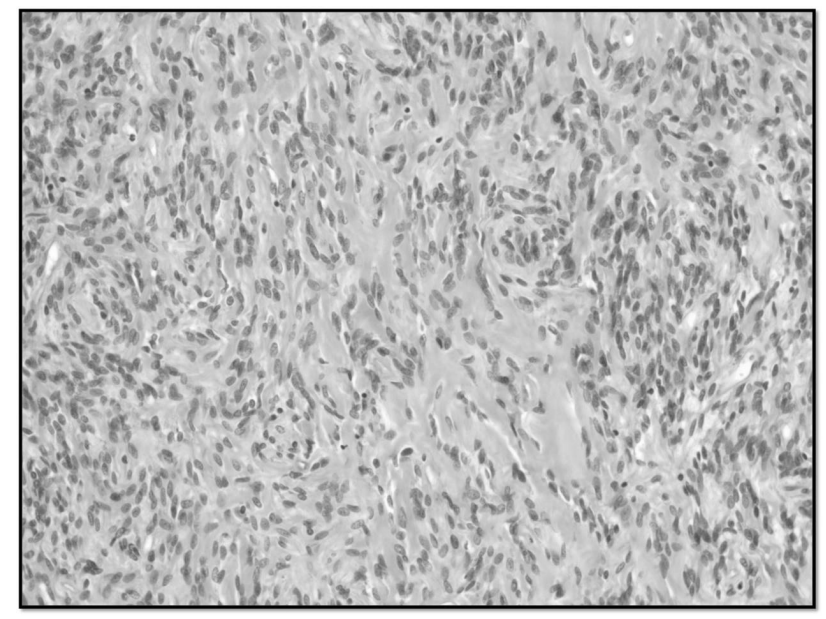

Slika 2. Solitarni fibrozni tumor pleure: vretenaste ćelije i snopovi sklerozirajućeg veziva, $H \& E x 10$.

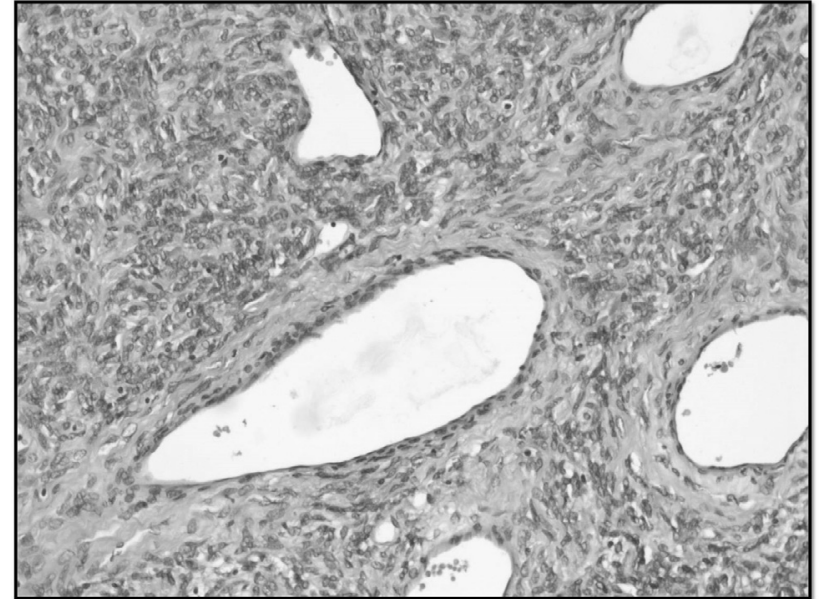

Slika 3. Solitarni fibrozni tumor pleure: razgranate vaskularne strukture, $H \& E x 40$.

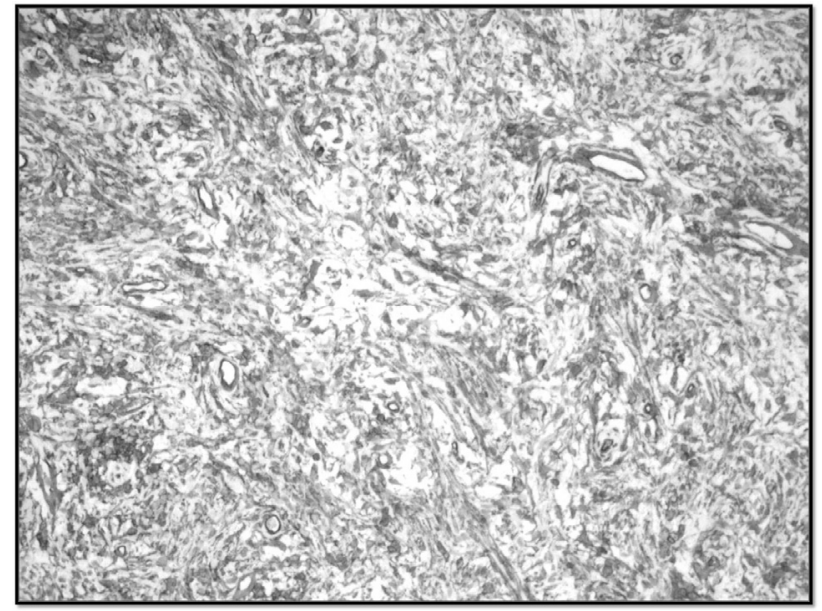

Slika 4. Pozitivnost tumorskih ćelija na CD34, x 10. 


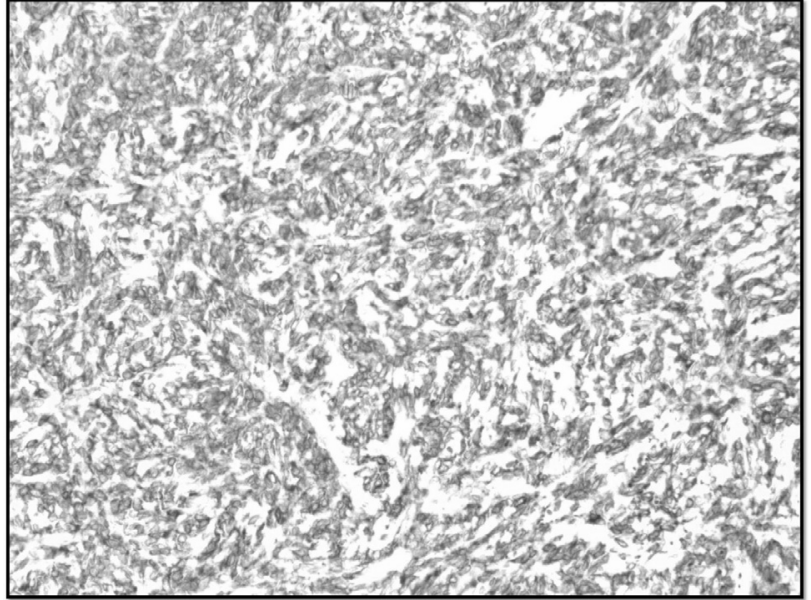

Slika 5. Pozitivnost tumorskih ćelija na Bcl-2, x 10.

\section{LITERATURA}

1. Cardillo G, Carbone L, Carleo F, Masala N, Graziano P, Bray A et al. Solitary Fibrous Tumors of the Pleura: An Analysis of 110 Patients Treated in a Single Institution. Ann Thorc Surg 2009; 88: 1632 1637.

2. Youcai Z, Kaiqi D, Deyun L. Solitary fibrous tumors of pleura and lung: report of twelve cases. J Thorac Dis. 2013; 5(3):310-313.

3. Demicco EG, Park MS, Araujo DM, Fox PS, Bassett RL, Pollock RE et al. Solitary fibrous tumor: a clinicopathological study of 110 cases and proposed risk assessment model. Modern Pathology, 2012; 25: 1298-1306.

4. Robinson LA. Solitary fibrous tumors of the pleura: review. Cancer Control 2006; 13: 264-269.

5. Yoshida A, Tsuta K, Ohno $M$, et al. STAT6 immunohistochemistry is helpful in the diagnosis of solitary fibrous tumors. Am J Surg Pathol 2014; 38:552.

6. Wagner E. Das tuberkelahniliche Lymphadenom (Der cytologene oder Reticulierte Tuberkel). Ann Hailk 1870; 11: 497.

7. Klemperer P, Rabin CB. Primary neoplasm of the pleura: a report of five cases. Arch Pathol 1931; 11: 385-412.

8. De Perrot M, Fisher S, Brundler MA, Sekine Y, Keshavjee. Solitary Fibrous Tumor of the Pleura. Ann Thorac Surg 2002; 74: 285-293.

9. Tagliabue F, Vertemati G, Confaionieri G, Romelli A, Terragni S, Costa M. Benign soliatry fibrous tumor of the pleura: a clinical review and report os six cases. Chirurgia Italiana 2005; 57(5): 649-653.

10. Altinok T, Topcu S, Tastepe AI, Yazici U, Cetin G. Localized fibrous tumors og the pleura: clinical and surgical evaluation. Ann Thorac Surg 2003; 76: 892895.

11. Thorgeirsson $\mathrm{T}$, Isaksson HJ, Hardardottir $\mathrm{H}$, Alfredsson H, Gudbjartsson T. Solitary fibrous tumors of the pleura: An Estimation of Population Incidence. Chest 2010; 137: 1005-1006.

12. England DM, Hochholzer L, McCarthy MJ. Localized benign and malignant fibrous tumors of the pleura: a clinicopathologic review of 223 cases. Am J Surg Pathol 1989; 13: 640-658.

13. Guo W, Xiao HL, Jiang YG, Wabg RW, Zhao YP, Zheng $\mathrm{M}$ et al. Retrospective analysis for thirty-nine patients with solitary fibrous tumor of the pleura and a review of the literature. World Jurnal of Surgical Oncology 2011; 9: 134.

14. Santambrogio L, Nosotti M, Palleschi L, Rosso L, Tosi D, Simone $\mathrm{M}$ et al. Solitary fibrous tumor of the pleura presenting with the syncope episodes when coughing. World Jurnal of Surgical Oncology 2008; 6: 86.

15. Chafik A, Alaoui M, Benjelloune A, Qamouss Y. A Solitary Fibrous Tumor of the Pleura Revealed by Hiccups. Case Reports in Medicine 2011; article 574319: 1-3.

16. Shaker W, Meatchi T, Dusser D, Riquet M. An unusual presentation of solitary fibrous tumor of the pleura: right atrium and inferior vena cava compression. Euro J Card-Thorac Surg 2002; 22(4): 640-642.

17. Cardillo G, Facciolo F, Cabazzana AO. Localized (solitary) fibrous tumors of the pleura: an analysis of 55 patients. Ann Thorac Surg 2000; 70: 1808-1812.

18. Sung SH, Chang JW, Kim J et al. Solitary fibrous tumor of the pleura: surgical outcome and clinical course. Ann Thorac Surg 2005; 79: 303-307.

19. Carretta A, Bandiera A, Melloni G, et al. Solitary fibrous tumors of the pleura: immunohistochemical analysis and evaluation of prognostic factors after surgical treatment. Journal of Surgical Oncology. 2006;94(1):40-44.

20. Vallat-Decouvelaere AV, Dry SM, Fletcher CD. Atypical and malignant solitary fibrous tumors in extrathoracic locations: evidence of their comparability to intra-thoracic tumors. Am J Surg Pathol 1998;22(12):1501-11.

21. Fletcher C. Tumors of soft tissue. In: Diagnostic histopathology of tumors. Churchill Livingstone, 2013; 1820-1821.

22. Lecoutere E, Creytens D. Multifocal cytokeratin expression in pleural and abdominal malignant solitary fibrous tumors: an unusual diagnostic pitfall. Virchows Arch. 2015; 467: 119-121: 
23. Mentzel T, Bainbridge TC, Katenkamo D. Solitary fibrous tumor: clinicopathological, immunohistochemical and ultrastructural analysis of 12 cases. Virchow Arch 1997; 430: 445-453.

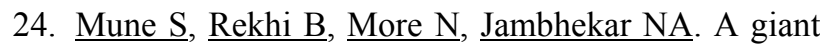
solitary fibrous tumor of the pleura: diagnostic implications in an unusual case with literature review. Indian J Pathol Microbiol. 2010;53(3):544-7.

25. Koelsche C, Schweizer L, Renner M, et al. Nuclear relocation of STAT6 reliably predicts NAB2-STAT6 fusion for the diagnosis of solitary fibrous tumour. Histopathology 2014; 65:613.

26. Demicco EG, Harms PW, Patel RM, et al. Extensive survey of STAT6 expression in a large series of mesenchymal tumors. Am J Clin Pathol 2015; 143:672.

27. Doyle LA, Vivero M, Fletcher CD, et al. Nuclear expression of STAT6 distinguishes solitary fibrous tumor from histologic mimics. Mod Pathol 2014; 27:390.

SUMMARY: Introduction: Solitary fibrous tumor of the pleura (SFTP) is a rare slow-growing primary pleural tumor that originates from cells of mesenchymal tissue located in pleural submesothelial layer. Objective: Analysis of 18 cases of SFTP with a focus on demographic, clinical-morphological, histological and immunohistochemical features of the neoplasm, especially in differentiating benign and malignant SFTP. Methods: Retrospective analysis of clinical datas from 18 patients with pathohistologically diagnosed solitary fibrous tumor of the pleura in 10-year period at Institute for Pulmonary Diseases of Vojvodina was performed. Results: The average patient age was 54 years. $61.1 \%$ of patients were female and $38.9 \%$ male. $44,4 \%$ of patients were smokers. Most common clinical manifestations were pain in the hemithorax (44,4\%), cough (38.8\%) and general infectious syndrome $(22,2 \%)$. The tumor was localized in $61.2 \%$ of patients in the right hemithorax, and in $38.8 \%$ in the left. The smallest diameter of the tumor was $2 \mathrm{~cm}$, and the largest $15 \mathrm{~cm}$. In only one case SFTP presented as malignant and in one case, due to the presence of necrosis, increased cellularity and size of $13 \mathrm{~cm}$, as tumor of uncertain malignant potential. Vimetin, CD34 and bcl-2 proved to be a reliable positive antibodies and CD31, EMA, desmin and panCK as reliable negative. Conclusion: The line between benign and malignant SFTP is not entirely clear, so, the definitive diagnostic and therapeutic procedures, as well as the prediction of disease must include all of the demographic, clinical and morphological and immunohistochemical data.

Key words: solitary fibrous tumor, pleura, diagnosis.

Aleksandra Lovrenski,

Put doktora Goldmana 4,

21204 Sremska Kamenica,

e-mail: ajalovrenski@gmail.com 